\title{
Research on Influence of Deep Foundation Pit Excavation and Dewatering on Pile Foundation of Railway Bridge
}

\author{
Liu Tianyun ${ }^{1 *}$, Yu Changyi ${ }^{1}$, and Zhu Nan ${ }^{1}$ \\ ${ }^{1}$ Tianjin Port Engineering Institute Company LTD. Of CCCC, CCCC First Harbour Engineering Company Ltd., Key Laboratory of Port \\ Geotechnical Engineering of Ministry of Communications, Key Laboratory of Port Geotechnical Engineering of Tianjin, Tianjin 300222, \\ China.
}

\begin{abstract}
The three-dimensional numerical model of the foundation pit engineering is established, and the fluid-structure coupling method is used to calculate the settlement of the pile foundation of the adjacent railway bridge caused by the excavation and dewatering of the foundation pit. The results show that the settlement range of the soil around the foundation pit reaches $140 \mathrm{~m}$, and the pile foundation of the railway bridge is within the influence range, but the maximum settlement value does not exceed the limit value specified in the design. The method used in this paper provides effective guidance for the construction optimization of the same type of projects and reduces the project cost.
\end{abstract}

\section{Introduction}

There are two adjacent foundation pits in the dumper room of a project, with the depth of $26 \mathrm{~m}$ and $19 \mathrm{~m}$ respectively, and a new railway bridge is near the foundation pit. The nearest distance between the edge of foundation pit and bridge is about $70 \mathrm{~m}$. Due to the excavation and dewatering during the construction of foundation pit, the surrounding soil will produce a certain settlement, which may cause the settlement of the pile foundation of the new railway bridge. If the settlement exceeds the design limit, the normal operation of the new railway will be affected. Therefore, through the establishment of a three-dimensional numerical model of foundation pit engineering, the fluid-structure coupling method is used to calculate the settlement of the pile foundation of the nearby railway bridge caused by excavation and dewatering. According to the calculated settlement value, the decision is made that whether to take preventive or reinforcement measures to ensure the smooth construction of the project and the safe operation of the new railway.

In the process of foundation pit excavation, due to the vertical and horizontal unloading of the soil, the deformation of the soil inside and outside the foundation pit is caused. At the same time, the dewatering of the foundation pit will change the seepage field inside the soil, affect the change of pore pressure in the soil and eventually lead to the deformation of the soil. Scholars at home and abroad have carried out a lot of research on this issue. The relationship between the deformation of the support structure, settlement of ground outside pit and anti-uplift safety factor of the foundation pit is studied by Mana through the finite element numerical analysis, and the relevant empirical formula is established [1]. Jin Xiaorong et al. studied the control method of ground settlement outside the pit, and established a two-dimensional finite element model to simulate the reinjection effect of controlling ground settlement outside the pit [2]. Luo Zujiang et al. established a three-dimensional seepage model to predict the deformation of groundwater level and land subsidence, which has high reliability [3]. Ye Weimin et al. analysed the fluid structure coupling of three different precipitation schemes by the numerical simulation method and compared the differences between each scheme [4]. Shen et al. establishes a numerical model for calculating ground subsidence based on three-dimensional groundwater seepage and one-dimensional Terzaghi consolidation theory, and the reliability of the simulation effect of the model is proved by comparing the calculated value of the model with the measured land subsidence [5]. In conclusion, there are many results of using numerical analysis method to study the influence of foundation pit excavation and dewatering on soil deformation. Numerical simulation method with the characteristics of low cost and high efficiency is an effective means to analyse the influence of the excavation and dewatering of the foundation pit.

\section{Numerical simulation scheme}

\subsection{Structural model}

In the foundation pit of the dumper room, the depth of the North foundation pit is $26 \mathrm{~m}$ with four internal supports, and the depth of the South foundation pit is $19 \mathrm{~m}$, with three internal supports. Cement mixing pile is used as waterproof curtain around the foundation pit. The length of the outer edge of the foundation pit is $109 \mathrm{~m}$ and the width is $59 \mathrm{~m}$. In order to eliminate the influence of boundary effect, the length, width and

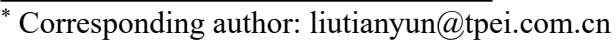


height of the soil model are $400 \mathrm{~m}, 400 \mathrm{~m}$ and $80 \mathrm{~m}$ respectively. According to the engineering geological conditions of the site, the soil is simplified into 10 layers, as shown in Fig. 1 and Fig. 2.

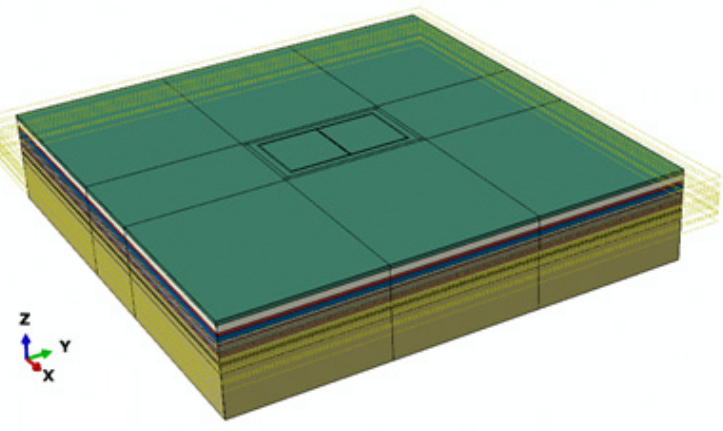

Fig. 1. Soil Model.

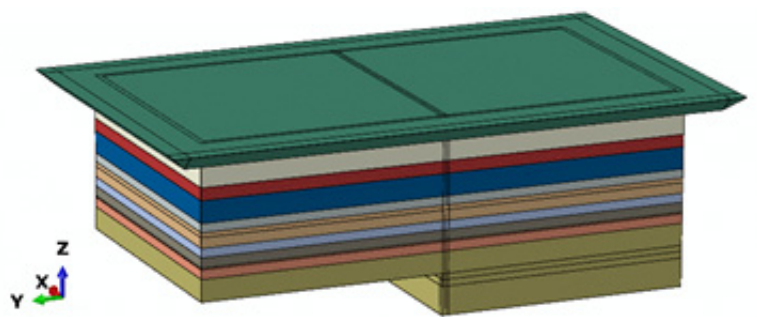

Fig. 2. Excavation soil model

In order to simplify the model, the concrete retaining piles at the outer edge of the foundation pit are simplified as the diaphragm wall according to the principle of equivalent bending stiffness. The equivalent diaphragm wall is shown in Fig. 3. The pile foundation model of the new railway bridge nearby and the internal support of the foundation pit are modelled according to the actual size, as shown in Fig. 4, Fig. 5 and Fig. 6.

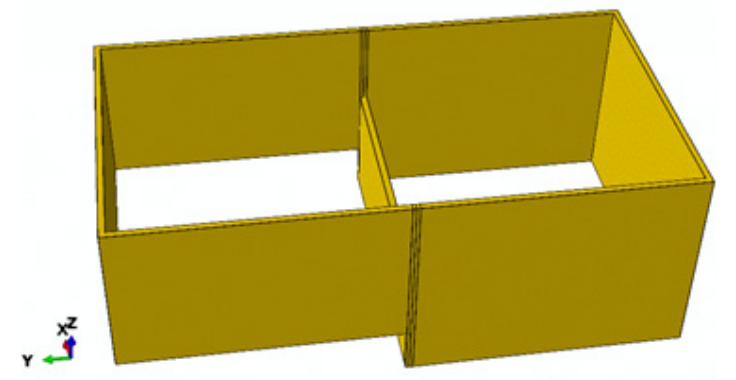

Fig. 3. Equivalent diagram of retaining structure

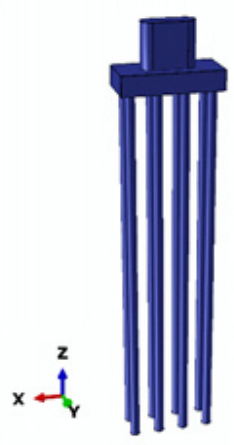

Fig. 4. Pile foundation structure of new railway bridge nearby

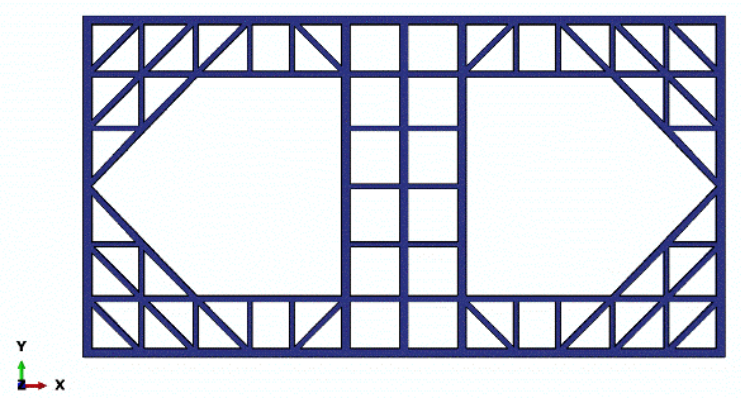

Fig. 5. Internal support structure of the 1st-3rd floor

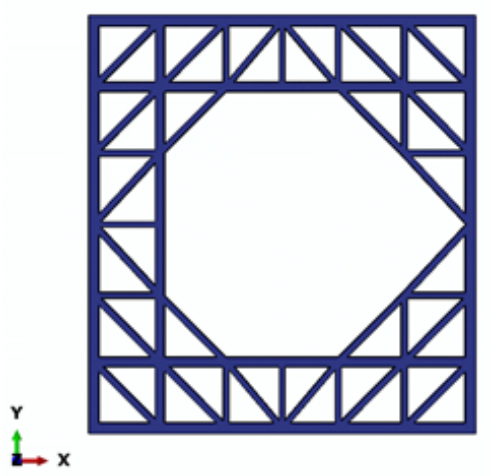

Fig. 6. Internal support structure of the 4 th floor

\subsection{Model parameter}

In the calculation, the influence of groundwater level on the calculation results is fully considered, the dry density is selected as the soil bulk density, and the initial geostress field is obtained by calculating the effective bulk density. The physical and mechanical parameters of each layer of soil are shown in Table 1.

Table 1. Physical and mechanical indexes of soil.

\begin{tabular}{|c|c|c|c|c|c|c|}
\hline Layer & \multirow{2}{*}{$\begin{array}{c}\text { Thickness } \\
(\mathrm{m})\end{array}$} & $\begin{array}{c}\text { Dry } \\
\text { density } \\
\left(\mathrm{kg} / \mathrm{m}^{3}\right)\end{array}$ & $\begin{array}{c}\text { Compression } \\
\text { modulus }\end{array}$ & $\begin{array}{l}\text { Poisson's } \\
\text { ratio }\end{array}$ & \multicolumn{2}{|c|}{ Shear strength } \\
\cline { 6 - 8 } & & & & $\mathrm{c}(\mathrm{kPa})$ & $\varphi\left({ }^{\circ}\right)$ \\
\hline 1 & 3.2 & 1490 & 6.44 & 0.32 & 25.5 & 18.3 \\
\hline 2 & 6.1 & 1220 & 5.52 & 0.35 & 22.4 & 14.6 \\
\hline 3 & 2.7 & 1460 & 7.20 & 0.32 & 23.8 & 15.5 \\
\hline 4 & 4.8 & 1700 & 15.33 & 0.33 & 27.9 & 21.8 \\
\hline 5 & 1.9 & 1700 & 6.40 & 0.33 & 46.0 & 17.3 \\
\hline 6 & 3.3 & 1520 & 16.08 & 0.31 & 23.2 & 24.5 \\
\hline 7 & 2.0 & 1500 & 13.20 & 0.34 & 23.8 & 15.5 \\
\hline 8 & 2.2 & 1500 & 11.34 & 0.33 & 24.9 & 21.8 \\
\hline 9 & 2.4 & 1530 & 15.20 & 0.30 & 46.0 & 17.3 \\
\hline 10 & 10.0 & 1710 & 17.84 & 0.28 & 27.0 & 18.5 \\
\hline
\end{tabular}

Linear elastic constitutive relation is used for bored pile, cement soil mixing pile and railway bridge pile foundation. The elastic modulus is obtained according to the principle of reinforcement ratio equivalence, and the values of relevant parameters are shown in Table 2. 
Table 2. Mechanical parameters of structure.

\begin{tabular}{|c|c|c|}
\hline Position & $\begin{array}{c}\text { Elastic modulus } \\
(\mathrm{GPa})\end{array}$ & Poisson's ratio \\
\hline Bored pile & 36.1 & 0.22 \\
\hline $\begin{array}{c}\text { Cement soil } \\
\text { mixing pile }\end{array}$ & 0.3 & 0.25 \\
\hline $\begin{array}{c}\text { Railway Bridge } \\
\text { Pile Foundation }\end{array}$ & 36.1 & 0.22 \\
\hline
\end{tabular}

\subsection{Numerical simulation process}

The numerical simulation analysis of foundation pit is divided into three steps.

The gravity field is applied to the whole soil model, and the in-situ stress balance is calculated to obtain the initial in-situ stress field.

In order to simulate the excavation of foundation pit, the unit birth and death method is used to remove the foundation pit soil within the excavation scope, and the diaphragm wall, internal support and railway bridge pile foundation are activated to simulate the construction process of each structure.

Steady state simulation is carried out for the foundation pit after excavation. Considering the influence of excavation on groundwater seepage in soil, the settlement of soil is calculated.

\section{Numerical simulation results}

\subsection{Analysis section}

Three representative pile foundation locations of the piers on the new railway line are selected, as shown in Fig. 7. The linear distance between pile 1, pile 2, pile 3 and the outer edge of foundation pit is $63 \mathrm{~m}, 66 \mathrm{~m}$ and $72 \mathrm{~m}$ respectively. Three parallel sections A1, B2 and C3 of foundation pit and railway pier are taken to analyse the settlement of soil outside the pit and the settlement of railway bridge pile foundation, to analyse the influence of the foundation pit excavation and dewatering on the railway bridge pile foundation.

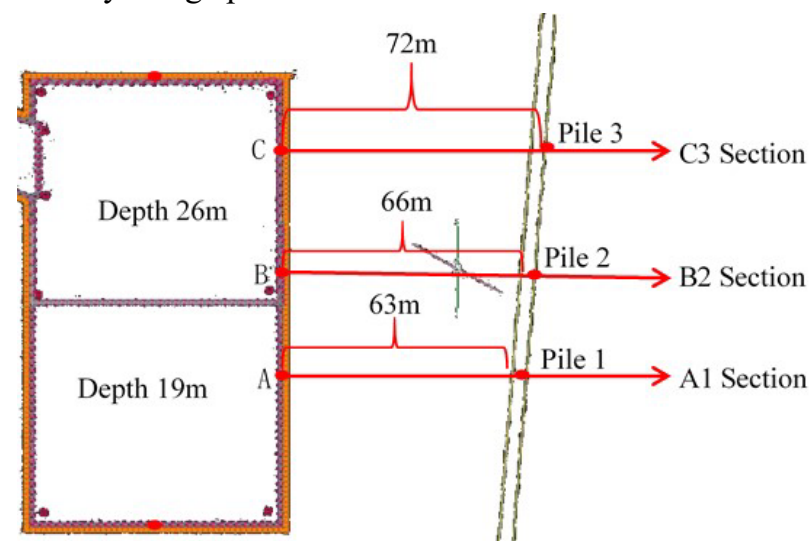

Fig. 7. Schematic diagram of analysis section and pile position

\subsection{Influence of the excavation and dewatering on the surrounding ground settlement}

The settlement of soil after foundation pit excavation and dewatering is shown in Figure 8. The negative value is downward settlement, and the positive value is upward uplift. It can be seen that the soil around the foundation pit has a large area of settlement, and the maximum settlement is $20.48 \mathrm{~mm}$. It can be seen from Figure 9 that the settlement range of foundation pit excavation dewatering reaches $140 \mathrm{~m}$ outside the foundation pit, and reaches the maximum value of soil settlement at $30 \mathrm{~m}$ outside the foundation pit. The maximum settlement of $\mathrm{A} 1, \mathrm{~B} 2$ and $\mathrm{C} 3$ sections is $20.46 \mathrm{~mm}, 18.19 \mathrm{~mm}, 18.19 \mathrm{~mm}$ respectively. Because of the existence of pile foundation of railway bridge, the ground settlement of three sections at distance from $63 \mathrm{~m}$, $66 \mathrm{~m}$ and $72 \mathrm{~m}$ of foundation pit is obviously reduced, but the settlement farther from the foundation pit continues to increase, which indicates that the pile foundation of railway bridge is in the influence range of soil settlement caused by foundation pit excavation and dewatering.
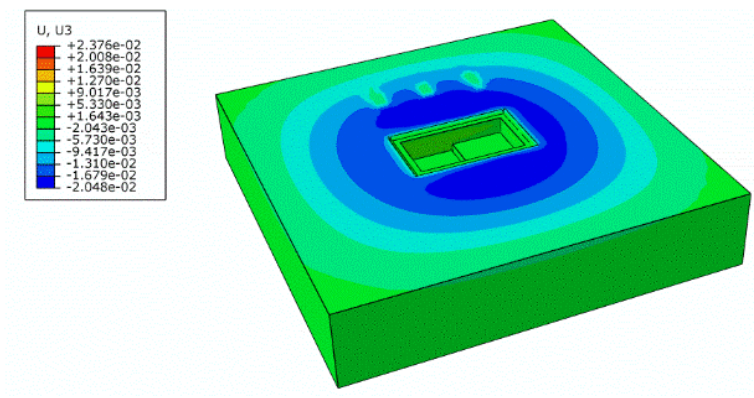

Fig. 8. Distribution of settlement after excavation and dewatering

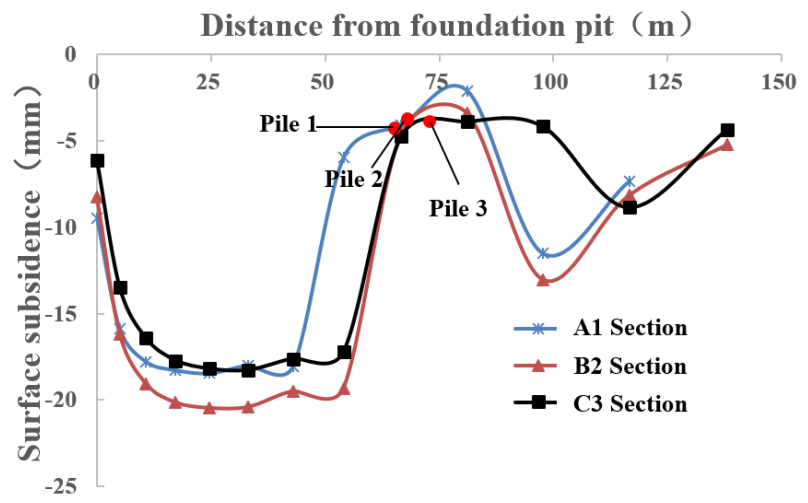

Fig. 9. Variation of settlement with horizontal distance from foundation pit

\subsection{Settlement of railway bridge pile foundation caused by excavation and dewatering}

According to the numerical simulation results, dewatering and excavation will cause the displacement of railway bridge pile foundation, as shown in Figure 10. Compared with the results of each pile foundation, excavation and dewatering have the greatest impact on the settlement of pile 2. The maximum settlement of pile 2 is $4.84 \mathrm{~mm}$, the minimum settlement is $3.15 \mathrm{~mm}$, and the settlement difference is $1.69 \mathrm{~mm}$. 


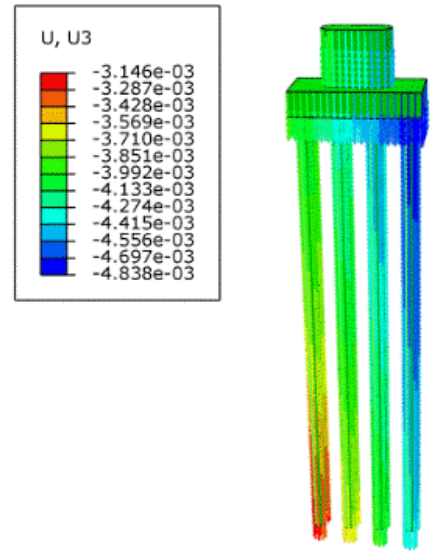

(a) Pile 1
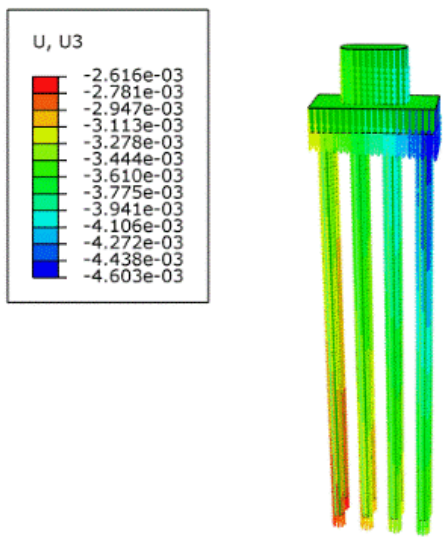

(b) Pile 2
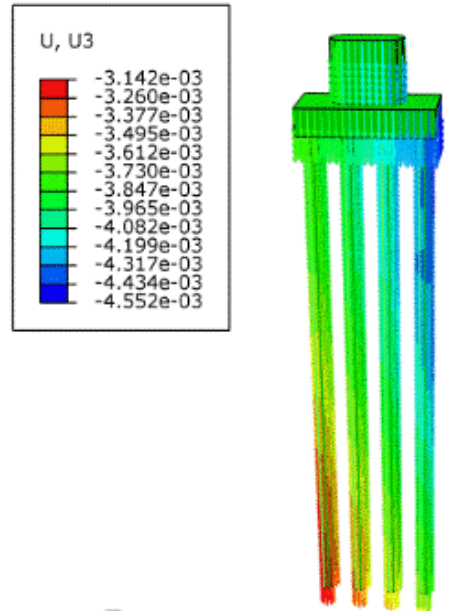

(c) Pile 3

Fig. 10. Settlement of railway bridge pile foundation

\section{Conclusion}

The excavation and dewatering of the foundation pit cause the settlement of the surrounding soil, and the maximum settlement reaches $20.48 \mathrm{~m}$. The settlement range of soil around the foundation pit reaches $140 \mathrm{~m}$ outside the foundation pit, and the pile foundation of Railway Pier is within the influence range of soil settlement caused by foundation pit excavation and dewatering. foundation pit will cause the settlement of the pile foundation of the new railway bridge nearby, and the maximum settlement is $4.84 \mathrm{~mm}$, which is less than the limit value specified in the design, so there is no need for preventive or reinforcement measures.

\section{References}

1. A. I. Mana. (1978) Finite Element Analysis of Deep Excavation Behaviour in Soft Clay: [Ph.D. Dissertation], California: Stanford University.

2. JIN Xiao-rong, YU Jian-lin, ZHU Shao-chen. (2005) Analysis behaviors of settlement of pit's surrounding soils by dewatering. Rock and Soil Mechanics, 26(10):1575-1581.

3. Luo Zu-jiang, Li Lang, Cao Hui-bin, et al. (2006) Numerical Simulation of Three-dimensional Seepage Field of a Deep Foundation Pit During Dewatering in a Complex Composite Aquifer System--Case Study of Dewatering of a Pit at The SHANGHAI Finance Center. Journal of Engineering Geology, 14(1):72-77.

4. Ye Wei-min, Wan min, Chen Bao, et al. (2009) Influence of Dewatering of Confined Aquifers on Land Subsidence During Deep Excavation. Chinese Journal of Underground Space and Engineering, 5(S2): 1799-1805.

5. S. L. Shen, Y. S. Xu. (2011) Numerical Evaluation of Land Subsidence Induced by Groundwater Pumping in Shanghai. Canadian Geotechnical Journal, 48(9): 1378-1392. 